\title{
K. D. WILKINSON
}

Kenneth Douglas Wilkinson was one of the original members of the Cardiac Club when it was formed in 1922, a member of the first Council of the British Cardiac Society, and for many years a member of the Editorial Board of the British Heart Journal. " He died on April 12, 1951, at his home in Edgbaston, only a few days before his 65th birthday, having made a recovery from at least two cardiac infarcts but later being slowly overwhelmed by a disease that defied all treatment. He bore his suffering and faced his end with characteristic fortitude and gaiety, continuing regularly to visit the wards until he was too faint to stand. To the last he was thoughtful for his patients and insisted on teaching his students, which he did in his own inimitable way.

Wilkinson and his brothers were brought up by their mother, for their father, Rev. H. C. Wilkinson, Vicar of High Leigh in Cheshire, had died when the children were young. The devotion, courage, and confidence that she showed had a profound influence on Wilkinson's character. She took a house in Berkhamsted to enable the boys to attend the school there and, some years afterward, moved with her family to Birmingham where Wilkinson qualified as a medical practitioner in 1909. A year before he had submitted an essay that was awarded the Richards Memorial prize, and he had won the senior prize in clinical medicine during his final year. He held resident posts in Birmingham at the Queen's and General Hospitals, took his M.D. in 1912, and was then appointed Casualty Officer at the Hospital for Sick Children, Great Ormond Street. His return to Birmingham was determined by his appointment to the staff of the Children's and General Hospitals. Shortly afterwards, being a Territorial, he went with the R.A.M.C. to France where he joined G. E. Gask's pioneer unit for the investigation and treatment of thoracic injuries. For his work in this field he was mentioned in dispatches and awarded the O.B.E.

Wilkinson had already shown his interest in cardiovascular disease and had written papers on heart block. His work in the Army increased his enthusiasm and, realizing that he needed further training if he were to specialize in the subject, he turned once again to London, where for about a year he worked with Thomas Lewis. Here the foundation was laid of enduring friendships with Lewis, Parkinson, Horder, Bramwell, and many others who had felt Mackenzie's influence. Once back in Birmingham he shared with J. G. Emanuel the task of providing a cardiological service for the Midlands and he was appointed consultant cardiologist to the Birmingham City Hospitals. At the Fever Hospital he took a great interest in the effect of diphtheria on the heart, while at the Children's Hospital and at Baskerville Residential School he investigated the natural history of rheumatic fever. He summarized his views about rheumatism in the Ingleby Lecture which he gave at the University of Birmingham in 1935. He taught from the first that acute rheumatism should be treated with massive doses of salicylate, and it gave him much satisfaction that in the last few years this view should have been more widely accepted. Believing firmly that salicylates have a specific action on the heart he was highly critical of all other remedies, including cortisone.

When he thought the occasion demanded it, he could be furiously aggressive and fearless in criticism, but it was more natural to him to enjoy the humour of life. He was at his best when with his friends at the Cardiac Society or at the Pædiatric Association. Many will remember him standing with hands deep in pockets, his chest thrust out and his chin tucked in, talking. His stance, the broad expanse of waistcoat, his gestures, and the twinkle in his eye had the same attractiveness as the quick, cheerful confidence of a robin. He loved to tell stories, and he did so supremely well. He could be witty in more than one language, and could speak in many dialects.

Whether in or out of doors he was usually to be seen with his cine camera or his Leica. He was equally delighted to show off the paces of his Lagonda, to play a game of bridge, golf or billiards, 





or to talk about sailing, collecting stamps, or keeping bees. He was a man of many interests, a most excellent companion, and a generous and thoughtful host.

For many years, with his friend Whitmore Peck, he collected information about William Withering, one of the first physicians at the Birmingham General Hospital. He told something of their discoveries on the memorable occasion when members of the Cardiac Society under his chairmanship dined at Withering's house in Birmingham in 1939. Ten years later he expanded this material into the St. Cyres lecture at the National Heart Hospital and in 1950, encouraged and helped by his wife, he completed and published his excellent biography. The book was enriched by reproductions of some of his magnificent collection of contemporary prints.

In addition to his other obligations Wilkinson formerly held the Chair of Pharmacology and Therapeutics at the University and more recently was elected Professor Emeritus. He examined at many Universities, he was Senior Physician at the Birmingham United Hospitals, and he ran a large consulting practice. A remarkably keen observer, outstanding as a clinician, he was by choice conservative, and was bitterly opposed to the new Health Service.

He was twice married; to Miss Phebe Homewood, a sister at the Queen's Hospital, who died in 1940, and to Dr. Agnes Crozier. His eldest son is a doctor, and his eldest daughter a trained nurse. His home was a great source of his happiness, and to the widow and to the seven children whom he has left we extend our deepest sympathy.

C. G. PARSONS 